\title{
Neuroscientific evidence support that chess improves academic performance in school
}

\author{
Ricardo Ortiz-Pulido ${ }^{1 *}$, Raúl Ortiz-Pulido², Luis I. García-Hernández³, César A. Pérez-Estudillo³ and \\ María L. Ramírez-Ortega ${ }^{4}$ \\ ${ }^{1}$ Dirección General Federalizada de Educación Física, Subsecretaría de Educación de Veracruz, Veracruz; ${ }^{2}$ Laboratorio de Ecología de Poblaciones, \\ Centro de Investigaciones Biológicas, Universidad Autónoma del Estado de Hidalgo, Hidalgo; ${ }^{3}$ Centro de Investigaciones Cerebrales, Universidad

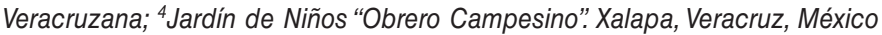

\begin{abstract}
In this work, we report the cognitive benefits of playing chess for school-aged children. The most benefitted areas appear to be math and reading. To validate these results, a diversity of scientific studies are described, in which brain activation is demonstrated through magnetic resonance imaging when novice, intermediate, and advance chess players play the game. Given this evidence, it is suggested that chess be used as a tool to improve academic performance in boys and girls. In addition, it is concluded that studying the use of chess could lead to new lines of research that could validate the neural mechanisms that occur when boys and girls play chess.
\end{abstract}

Key words: Chess. School. Boys. Girls. Academic performance.

\section{Evidencia neurocientífica apoya que el ajedrez mejora el rendimiento académico en la escuela}

\section{Resumen}

En este trabajo se reportan los beneficios cognitivos que produce la práctica del ajedrez en niños en edad escolar. Las áreas más beneficiadas parecen ser las matemáticas y la lectura. Para validar lo anterior se describen diversos trabajos científicos que muestran la activación cerebral a través de imágenes de resonancia magnética cuando los jugadores de ajedrez novatos, intermedios o avanzados practican este juego. Con base en ello se sugiere usar el ajedrez como una herramienta que permita la mejora del rendimiento escolar en niños y niñas. Se concluye además que a partir de la utilización de este juego se pueden generar líneas de investigación que busquen validar mecanismos neurales que ocurren cuando niños y niñas juegan ajedrez.

Palabras clave: Ajedrez. Escuela. Niños. Niñas. Rendimiento escolar.

\section{Correspondence:}

*Ricardo Ortiz Pulido

Calletano Rodríguez Beltrán, s/n

Col. Centro

Date of reception: 25-09-2018

Date of acceptance: 06-06-2019

E-mail: pulidoortizricardo@gmail.com
Available online: 09-08-2019 Rev Mex Neuroci. 2019;20(4):194-199 www.revmexneurociencia.com 1665-5044/O 2019. Academia Mexicana de Neurología A.C. Published by Permanyer México. This is an Open Access article under the terms of the CC BYNC-ND license (http://creativecommons.org/licenses/by-nc-nd/4.0/) 


\section{Introduction}

Chess is a game that allows the transfer of cognitive abilities ${ }^{1}$. This is due to the fact that it involves high-level cognitive aspects, requires sophisticated problem-solving abilities ${ }^{2-5}$, has a positive impact on academic achievements of those who play it ${ }^{6}$ and positive effects on mental development. This may be because, during the game of chess, cognitive abilities ${ }^{7}$ such as creativity, anticipation, perception, and memory ${ }^{5}$ are used. Chess, in addition, offers an opportunity to study individual differences in cognitive processes ${ }^{3}$.

Regardless of grade level, chess can be used as a learning tool in boys and girls, since this game allows them to self-regulate their learning and reach specific objectives $^{8}$. In addition, through divers chess problems, the level of knowledge of boys and girls in similar activities can be determined ${ }^{9}$. This is because chess has a complex rule system, and knowledge depends on each student's individual level ${ }^{5}$. Similarly, regardless of the level of the game performance of each individual, neuroimaging studies have shown brain activation during game play ${ }^{10}$.

The objective of this work is to present scientifically validated information demonstrating that chess is a useful tool for improving boys' and girls' academic performance in school. To do so, diversity of studies is described in which chess players are evaluated using functional magnetic resonance imaging (fMRI). After analyzing these studies, we suggest that chess can be used as a tool to improve learning in school-aged boys and girls.

\section{Chess in schools}

Playing chess, both in and outside of school, has a large potential for developing academic knowledge in children $^{11,12}$. In Mexico, the level of academic performance by each child can be quantified, since their performance is evaluated and they receive a grade score for their performance in mathematics and Spanish. However, chess playing is not graded. Even so, a variety of benefits, apparently indicating a positive impact of playing chess on mathematics and reading scores have been reported.

In recent studies, it has been reported that teaching chess yields benefits in school $7,9,11,13,14$. These benefits have been detected, particularly in children's math ${ }^{12,15-21}$ (Table 1) and reading comprehension scores ${ }^{22-25}$ (Table 2), though the effect is not the same between the two subjects. According to a recent meta-analysis evaluating which of the two subject areas (math or reading) is most benefitted, the area most positively impacted was math ${ }^{26}$. This may be because the game cultivates a high level of non-specific skills (for example, persistence, self-control, objectivity, memory, and problem-solving) which are relevant to academic performance overall ${ }^{27}$.

Playing and training for chess have been considered an important learning tool in education ${ }^{12}$, leading to some institutions to incorporate it into their school curricula ${ }^{1}$ or as an afterschool extracurricular activity. Notwithstanding, increased dissemination of the benefits of this game among education officials at the federal, state, and municipal levels is needed so that they will support initiatives in favor of educational spaces in the schools, and as such, bring the benefits of chess to schools.

Chess allows boys and girls to obtain benefits in diverse cognitive areas $4,11,16,22,28$; it has been shown that subjects that play chess improves their spatial reasoning, long-term planning, decision-making, memory ${ }^{11}$, cognitive development, academic performance $^{4,5}$, and strategic, creative, and critical thinking ${ }^{5}$. At the same time, chess can be used to evaluate cognitive processes, for example, by asking children to place the game pieces on the board in random order or standard positions ${ }^{29}$. However, further investigation is needed to describe the effects of this science game.

In this work, we describe some of the research reporting a positive effect of chess on academic performance, spatial concepts, executive functions, and basic cognitive, and social skills.

\section{Studies evaluating the effects of chess}

The results presented here showed a positive effect on the educational process of boys and girls who received training in chess.

In a study in Seoul, South Korea, it was found that presenting students with a heuristic chess problem were helpful for evaluating students' intellectual levels and using that knowledge, choose adequate methodologies for improving each student's level of academic performance ${ }^{1}$. The study was carried out among 38 students aged 8-12, divided into two categories: (1) those with high intellectual level and (2) those at risk of failing the school year, from three different primary schools ${ }^{1}$.

Another study showed that a group that trained in chess improved basic skills (i.e., attention and 
Table 1. Some of the research in which chess has been found to impact mathematics performance in school

\begin{tabular}{|c|c|c|c|c|c|}
\hline Author(s) & Country & $\mathbf{N}$ & Study objective & Tests & Results \\
\hline $\begin{array}{l}\text { Fernández-Amigo } \\
\text { et al. } .^{15}\end{array}$ & Spain & $\begin{array}{l}\mathrm{N}=141 \text { experimental } \\
\text { group ( } 79 \text { boys, } 62 \\
\text { girls) }\end{array}$ & $\begin{array}{l}\text { Analyze, qualitatively and } \\
\text { quantitatively, the utility of } \\
\text { instructional materials } \\
\text { using chess for teaching } \\
\text { mathematics during the } \\
\text { second grade of primary } \\
\text { school }\end{array}$ & $\begin{array}{l}\text { EFAI ("Evaluación } \\
\text { factorial de las } \\
\text { aptitudes intelectuales", } \\
\text { in English, Factorial } \\
\text { Evaluation of } \\
\text { Intellectual Aptitudes) }{ }^{29} \\
\text { Numerical score, } \\
\text { reasoning score, } \\
\text { ethnographic interview, } \\
\text { surveys }\end{array}$ & $\begin{array}{l}\text { Satisfaction was } \\
\text { achieved in the } \\
\text { utility of the chess } \\
\text { - based learning } \\
\text { materials for } \\
\text { teaching } \\
\text { mathematics }\end{array}$ \\
\hline Achig ${ }^{17}$ & Ecuador & $\begin{array}{l}\mathrm{N}=35 \text { experimental } \\
\text { group ( } 20 \text { boys, } \\
15 \text { girls) }\end{array}$ & $\begin{array}{l}\text { Test the impact of chess } \\
\text { on logical-mathematical } \\
\text { reasoning in sixth-grade } \\
\text { primary school students }\end{array}$ & $\begin{array}{l}\text { Theoretical chess test } \\
\text { before and after, } \\
\text { Mathematics class } \\
\text { score }\end{array}$ & $\begin{array}{l}\text { The average math } \\
\text { class score } \\
\text { increased }\end{array}$ \\
\hline Guerrero et al. ${ }^{18}$ & Mexico & $\begin{array}{l}\mathrm{N}=32 \text { The number } \\
\text { of boys versus girls } \\
\text { is not given }\end{array}$ & $\begin{array}{l}\text { Describe the effect of } \\
\text { chess on basic } \\
\text { mathematical operations } \\
\text { in fifth-grade primary } \\
\text { school students }\end{array}$ & $\begin{array}{l}\text { Pre-test and post-test } \\
\text { on fractions and } \\
\text { operations based on } \\
\text { ENLACE } 2011 \text { and } 2012 \\
\text { test questions, surveys } \\
\text { and interviews }\end{array}$ & $\begin{array}{l}\text { Better } \\
\text { concentration, } \\
\text { and memory and } \\
\text { higher math class } \\
\text { score }\end{array}$ \\
\hline $\begin{array}{l}\text { Gumede and } \\
\text { Rosholm }{ }^{19}\end{array}$ & Denmark & $\begin{array}{l}\mathrm{N}=264 \text { The number } \\
\text { of boys versus girls } \\
\text { is not given }\end{array}$ & $\begin{array}{l}\text { Characterize the impact of } \\
\text { chess in the subject of } \\
\text { mathematics in first-and } \\
\text { third-grade primary school } \\
\text { students }\end{array}$ & $\begin{array}{l}\text { Pre-intervention tests, } \\
\text { characteristics of the } \\
\text { child and the child's } \\
\text { mother and father }\end{array}$ & $\begin{array}{l}\text { Positive effects in } \\
\text { both immigrant } \\
\text { and non-immigrant } \\
\text { Danish children }\end{array}$ \\
\hline Sala et al. ${ }^{20}$ & Italy & $\begin{array}{l}\mathrm{N}=309 \text { experimental } \\
\text { group (169 boys, } 140 \\
\text { girls). } \\
\mathrm{N}=251 \text { control } \\
\text { group (116 boys, } 135 \\
\text { girls). }\end{array}$ & $\begin{array}{l}\text { Investigate the potential } \\
\text { of online chess lessons on } \\
\text { problem-solving abilities } \\
\text { in second, fourth, and } \\
\text { fifth-grade primary school } \\
\text { students }\end{array}$ & $\begin{array}{l}\text { Programme for } \\
\text { International Student } \\
\text { Assessment and chess } \\
\text { survey following } \\
\text { Trinchero }^{28} \text { Item } 12\end{array}$ & $\begin{array}{l}\text { Highly positive } \\
\text { correlation } \\
\text { between math } \\
\text { score and chess } \\
\text { in the } \\
\text { experimental } \\
\text { group }\end{array}$ \\
\hline Sala et al. ${ }^{21}$ & Italy & $\begin{array}{l}\mathrm{N}=309 \text { experimental } \\
\text { group } \\
\text { (169 boys, } 140 \text { girls) } \\
\mathrm{N}=251 \text { control } \\
\text { group ( } 116 \text { boys, } 135 \\
\text { girls) }\end{array}$ & $\begin{array}{l}\text { Experimental study of } \\
\text { chess in fourth grade } \\
\text { primary school students } \\
\text { using a placebo group }\end{array}$ & $\begin{array}{l}\text { Six tests evaluating } \\
\text { mathematics abilities, } \\
\text { IEA - TIMSS }{ }^{31} \\
\text { psychometric test }\end{array}$ & $\begin{array}{l}\text { The chess group } \\
\text { was more } \\
\text { effective in math } \\
\text { skills than the } \mathrm{GO} \\
\text { group, but not in } \\
\text { school activities }\end{array}$ \\
\hline Rosholm et al. ${ }^{12}$ & Denmark & $\begin{array}{l}\mathrm{N}=323 \text { experimental } \\
\text { group. } \mathrm{N}=159 \\
\text { control group }\end{array}$ & $\begin{array}{l}\text { Analyze the effect of } \\
\text { replacing one } \\
\text { mathematics lesson per } \\
\text { week with one based on } \\
\text { chess instruction in first } \\
\text { and third grade primary } \\
\text { school students }\end{array}$ & $\begin{array}{l}\text { Mathematics } \\
\text { test (including } \\
\text { calculations, geometry, } \\
\text { pattern recognition, and } \\
\text { basic problem solving) }\end{array}$ & $\begin{array}{l}\text { Improvement in } \\
\text { the composition of } \\
\text { mathematical } \\
\text { sequences in the } \\
\text { experimental } \\
\text { group }\end{array}$ \\
\hline
\end{tabular}

memory), complex cognitive skills (e.g., association, analysis, synthesis, planning, and foresight), and social-personal skills, compared to two control groups - one that did not participate in chess or any sport and another that played soccer and basketball ${ }^{14}$.

In another study, the effect of training in chess in 6-year-old children showed an increase in spatial concept comprehension compared to a group of children that did not play chess ${ }^{7}$; and finally, a study showed that children who trained in chess had higher results on evaluations of executive function than those that did not ${ }^{13}$.

These results have caught the attention of neuroscientists, who have begun to describe brain activation when children participate in the game of chess. 
Table 2. List of research papers investigating the impact of chess on reading comprehension in school

\begin{tabular}{|c|c|c|c|c|c|}
\hline Author(s) & Country & $\begin{array}{l}\text { Number of } \\
\text { participants }\end{array}$ & Study objective & Tests & Results \\
\hline Margulies et al. ${ }^{22}$ & $\begin{array}{l}\text { United } \\
\text { States of } \\
\text { America }\end{array}$ & $\begin{array}{l}N=1118 \text { Groups } \\
\text { of participants } \\
N=22\end{array}$ & $\begin{array}{l}\text { Escribe the effect on } \\
\text { reading before and } \\
\text { after chess instruction } \\
\text { in primary school }\end{array}$ & $\begin{array}{l}\text { Degree of reading } \\
\text { power test (DRP) }\end{array}$ & $\begin{array}{l}\text { The group of chess students } \\
\text { improved more than the } \\
\text { average student }\end{array}$ \\
\hline Liptrap et al. ${ }^{23}$ & $\begin{array}{l}\text { United } \\
\text { States of } \\
\text { America }\end{array}$ & $\begin{array}{l}N=571 \text { total } \\
\text { Chess group } \\
N=67 \text { Group } \\
\text { that did not play } \\
\text { chess } N=504\end{array}$ & $\begin{array}{l}\text { Determine the } \\
\text { degree of } \\
\text { participation by } \\
\text { students in a chess } \\
\text { club }\end{array}$ & $\begin{array}{l}\text { Texas Assessment of } \\
\text { Academic } \\
\text { Skills (TAAS). Texas } \\
\text { Learning Index (TLI) }\end{array}$ & $\begin{array}{l}\text { The chess group improved } \\
\text { more in math skills than in } \\
\text { reading }\end{array}$ \\
\hline Duccette ${ }^{24}$ & $\begin{array}{l}\text { United } \\
\text { States of } \\
\text { America }\end{array}$ & $\begin{array}{l}\text { Experimental } \\
\text { group } \mathrm{N}=151\end{array}$ & $\begin{array}{l}\text { Analyze the effect of } \\
\text { a chess program on } \\
\text { behavior, math, and } \\
\text { reading }\end{array}$ & $\begin{array}{l}\text { Philadelphia's } \\
\text { behavior grade and } \\
\text { attendance, } \\
\text { Pennsylvania System } \\
\text { of school } \\
\text { Achievement (PSSA) } \\
\text { score in Reading and } \\
\text { mathematics }\end{array}$ & $\begin{array}{l}\text { After } 1 \text { year, the group that } \\
\text { played chess improved in } \\
\text { math and reading, and these } \\
\text { values were correlated, while } \\
\text { in the control group none of } \\
\text { these patterns were present }\end{array}$ \\
\hline Dapica-Tejada ${ }^{25}$ & Spain & $\begin{array}{l}\mathrm{N}=60 \text { Total } \\
\text { Chess group } \\
\mathrm{N}=30 \text { ( } 21 \text { boys, } \\
9 \text { girls) } \\
\text { Control Group } \\
\mathrm{N}=30 \text { ( } 20 \text { boys, } \\
10 \text { girls) }\end{array}$ & $\begin{array}{l}\text { Test whether there } \\
\text { are significant } \\
\text { differences in reading } \\
\text { comprehension and } \\
\text { saccadic } \\
\text { movements }\left(\mathrm{SM}^{*}\right) \text { in } \\
\text { boys and girls that } \\
\text { play chess }\end{array}$ & $\begin{array}{l}\text { Chess participation } \\
\text { survey, PROLEC-SE } \\
\text { battery of tests of } \\
\text { reading processes and } \\
\text { the King Devick SM } \\
\text { test }\end{array}$ & $\begin{array}{l}\text { The chess group improved on } \\
\text { the different tests by which } \\
\text { they were evaluated, which } \\
\text { did not occur in the no-chess } \\
\text { group. In addition, there was } \\
\text { a correlation between SM } \\
\text { and reading comprehension } \\
\text { and between chess and SM }\end{array}$ \\
\hline
\end{tabular}

*SM are produced in the eyes when we read, look, or search for information, refers to movement speeds of $500^{\circ} / \mathrm{S}$. During these MS, the eyes can remain still for intervals of around $200-300 \mathrm{~ms}$.

\section{Brain activation while playing chess}

fMRI is one of the most important scientific advances since it allows the development of the cognitive sciences in ways never seen before. This is because fMRI allows a detailed study of brain cartography, and therefore, characterization of brain functions. fMRI is a technique that can measure hemodynamic changes after neuronal activity ${ }^{32}$. fMRI detects brain activity by directly measuring tissue perfusion, changes in blood volume, and changes in oxygen concentration ${ }^{33}$.

We see four main studies that can be used to describe how fMRI is used to investigate cognitive processes in chess players. These studies have demonstrated differential activation of the brain ${ }^{2,34-36}$ during games of novices and experts ${ }^{37}$.

One of these studies was carried out using novice chess players. fMRI results showed brain region associations that are activated during the analysis of game positions. These regions are the premotor areas, frontal lobes, parietal cortices, occipital lobe, and the left hemisphere of the cerebellum².
Another study showed that among expert chess players, there is no difference in the areas of brain activity; however, when their patterns of brain activity were compared to those of novice players, there were differences, since the novices produced activation among the posterior areas of both hemispheres, which did not occur among the expert players ${ }^{34}$.

The third scientific study was carried out using both novice and expert chess players. This study aimed to determine whether the subjects recognize general and specific patterns in chess. The experiment consisted of putting the game pieces on the board at random and instructing the subjects to recognize and analyze the patterns of the pieces using their eye movements. The results showed that while novice players examine irrelevant aspects, the expert chess players focused immediately on relevant aspects of the task. To corroborate this difference, the experiment was done using $\mathrm{fMRI}$, which allowed the description of differences in patterns of general and specific recognition. In the novice players, there was activation in the temporal-occipital area, while in experts, who were able to recognize specific objects 
during the test, there was bilateral activation in the middle part of the collateral sulci. This experiment showed evidence suggesting that subjects are able to identify general and specific patterns in chess; in addition, it describes the cognitive process they used. As such, this work could help describe essential perceptive mechanisms in humans ${ }^{35}$.

The last study we will comment on was carried out with novice players who had been training for only a short time and expert players with years of intensive training. $\mathrm{fMRI}$ was used to characterize their neuronal activity. The results suggest that specific training activated or inhibited specific brain structures, such as the bilateral caudate nucleus. At the same time, the volume of brain activity in that area was significantly smaller in experts than in novices ${ }^{36}$.

Despite the costliness of fMRI testing, the effects of playing chess have been investigated for many years ${ }^{38}$. As a consequence, the recent discoveries in neurosciences using neuroimaging techniques could allow the description of the underlying neural mechanisms of chess playing ${ }^{2,34-36}$, establish a correlation in the theory of the mind ${ }^{39}$ and identify common high level areas in cognitive processes, which could result in new theories of cognitive process ${ }^{2}$ or exploration of higher functions of the human brain ${ }^{40}$. In any case, we believe that there is a link between playing chess, increased academic performance in school, and the fMRI results.

Finally, we believe that the studies described above could lay the neuroscientific foundation for new scientific research on chess and other board games.

\section{Brain activation in games other than chess}

It is possible that the academic improvement in boys and girls could be achieved not only through playing chess but also through other similar games. It is, therefore, important to consider what is known about the effects of other games on activation of different brain areas.

For example, one study analyzed the brain activity of 28 professional and amateur players of the board game Shogi. The average age of the subjects was 30.6 years. In the professional players, there was activation in specific brain areas, particularly in the precuneus of the parietal lobule during the perception of patterns on the board, and in the caudate nucleus of the basal ganglia when the players were carrying out their "best move." Considering these results, the researchers suggest that the precuneus-caudate circuit is involved in the automatic patterns of the process of pattern perception on the board and the perception of the next move ${ }^{37}$.

Another study was carried out among university students (not professionals) with the aim of describing which brain areas are activated when subjects participate in the game GO. The fMRI results showed that the activated areas were the cortical, prefrontal, parietal, occipital posterior temporal, primary somatosensory system, and motor areas. It is thought that this type of activation may be due to the fact that the game emphasizes an overall strategy rather than a specific strategy, as occurs in chess ${ }^{41}$.

Although analyzing the rules and other characteristics of Shogi, Go, and chess, reveal clear differences among them, it is important to emphasize that the studies described used fMRI and have helped to describe which brain areas are most active while these games are being played. In the near future, it is possible that a cognitive model of learning could be described for games other than chess from the perspective of neuroscience or other cognitive models.

\section{Conclusions}

In this review, we have described the benefits and favorable academic effects in boys and girls in the school setting, as well as the neuronal activation that occurs when playing chess. As such, we consider that playing this game could be a viable strategy for improving expected learning and relevant knowledge in boys and girls ${ }^{42}$, as long as the educator that works with them keeps them motivated in a fun, collaborative environment ${ }^{14}$.

In several countries, this strategy has been used to improve academic performance, for example, in Mexico, where ENLACE academic evaluations ${ }^{43}$ during primary school and Programme for International Student Assessment evaluations in the secondary school show that girls and boys are below the worldwide average ${ }^{44}$. In addition, we believe that using the foundations described here, new lines of research could be generated, considering the game of chess as a potential catalyst for academic improvement in boys and girls.

\section{Conflicts of interest}

There are no conflicts of interest for the authors of this work. 


\section{Funding}

The authors declare that there were no funding sources for the elaboration of this manuscript.

\section{Acknowledgments}

We thank the Subsecretary of Education of Veracruz, especially Lic. Javier Ramírez Cruz, Lic. Miguel Roberto Rodríguez Flores and Mtro. Maestro Bruno Renato Flores Suarez, for lending facilities for writing this paper. Thanks to Mtro. Darío Arcos Monfil, Mtro. José Gary Zilly, L.E.F. Mauricio Ortiz Téllez y L.E.F. Carlos Martínez Mendieta for diverse academic discussions at the Centro de investigación de la Dirección Federalizada de Educación Física de Veracruz, which focused this work.

\section{References}

1. Hong S, Bart, W. Cognitive Effects of Chess Instruction on Students at Risk for Academic Failure. En Proceedings of the $7^{\text {th }}$ International Conference on Learning Sciences. International Society of the Learning Sciences; 2006. p. 938-9.

2. Atherton M, Zhuang J, Bart WM, Hu X, He S. A functional MRI study of high-level cognition. I. The game of chess. Brain Res Cogn Brain Res. 2003;16:26-31.

3. Charness N. The impact of chess research on cognitive science. Psychol Res. 1992;541:4-9.

4. Aciego R, García L, Betancort M. The benefits of chess for the intellectual and social-emotional enrichment in schoolchildren. Span J Psychol. 2012 15:551-9.

5. Gliga F, Flesner, PI. Cognitive benefits of chess training in novice children. Procedia Soc Behav Sci. 2014;16:962-7.

6. Jerrim J, Macmillan L, Micklewright J, Sawtell M, Wiggins, M. Does teaching children how to play cognitively demanding games improve thei educational attainment? Evidence from a randomised controlled trial of chess instruction in England. J Hum Ressourc. 2018; 53:993-1021.

7. Sigirtmac AD. Does chess training affect conceptual development of sixyear-old children in Turkey? Early Child Dev Care. 2012;192:797-806.

8. Welmeyer M, Palmer S, Agran M, Mithaug D, Martin J. Instruction students to become causal agents in their lives: the self-determining learning model of instruction exceptional children. Except Child. 2000;66: 439-53.

9. I Rius JB. Diseño y validación de un test de ajedrez-T23-para niños de 9 a 12 años. Agora Para Educ Física Deporte. 2014;16:18-35.

10. Hänggi J, Brütsch K, Siegel AM, Jäncke L. The architecture of the chess player's brain. Neuropsychologia 2014;62:152-62.

11. Nicotera A, Stuit D. Literature Review of Chess Studies. Saint Louis: chess Club and Scholastic Center of Saint; 2014. p. 34.

12. Rosholm M, Mikkelsen MB, Gumede K. Your move: the effect of chess on mathematics test scores. PLoS One. 2017:12:e0177257.

13. Grau-Pérez G, Moreira K. Estudio del Impacto del Ajedrez Sobre las Funciones Ejecutivas en Niños de Edad Escolar. La Plata: facultad de Psicología de la Universidad Nacional de La Plata; 2015. p. 3.

14. Aciego R, García L, Betancort M. Efectos del método de entrenamiento en ajedrez con escolares. Univ Psychol. 2015;15:165-76.

15. Fernández-Amigo J, Gairín Sallán J. Utilización de Material Didáctico con Recursos de Ajedrez Para la Enseñanza de las Matemáticas Barcelona. España: universidad de Barcelona; 2008

16. Kazemi F, Yektayar M, Abad AM. Investigation the impact of chess play on developing meta-cognitive ability and math problem-solving power of students at different levels of education. Procedia Soc Behav Sci. 2012 32:372-9.

17. Achig F. Artículo Científico-Incidencia de la Enseñanza del Ajedrez en la Asignatura de Matemáticas en los y las Estudiantes del 6to. año de
Educación Básica de la Unidad Educativa Hermano Miguel de la Salle-Cuenca en el Período de Enero a Junio de 2012-2015.

18. Guerrero SG, Martínez RM, Alonzo MM. EL ajedrez para el aprendizaje de operaciones básicas y números fraccionarios en un grupo de quinto grado de educación primaria. Rev Invest Educ Esc Grad Educ. 2015; 6:9-14.

19. Gumede K, Rosholm M. Your Move: the Effect of Chess on Mathematics Test Scores. Discussion Paper; 2015.

20. Sala G, Gorini A, Pravettoni G. Mathematical problem-solving abilities and chess: an experimental study on young pupils. SAGE Open. 2015 5:2158244015596050.

21. Sala G, Gobet F, Trinchero R, Ventura S. Chess instruction enhance mathematical ability in children? A three group design to control for placebo effects. In: does Chess Instruction Enhance Mathematical Ability in Children? Philadelphia, PA: a Three Group Design to Control for Placebo Effects; 2016.

22. Margulies S. The Effect of Chess on Reading Scores. Report. Vol. 10 New York: the American Chess Foundation; 1991. p. 13-25.

23. Liptrap JM. Chess and Standar Test Score. London: chess Life; 1998. p. 41-3.

24. DuCette J. An Evaluation of the Chess Challenge Program of ASAP/ After school Activities Partnerships. Philadelphia, PA: after School Activities Parnerships; 2009. p. 1-13.

25. Dapica-Tejada R. Influencia del Ajedrez en la Comprensión Lectora y los Movimientos Sacádicos en Niños Madrid. España: universidad Internacional de la Rioja; 2016

26. Sada G, Gobet F. Do the benefits of chess instruction tranfer to academic and cognitive skills? A meta-analysis. Educ Res Rev. 2016;18:46-57.

27. Costa AL, Kallick B. Habits of Mind Across the Curriculum: practical and Creative Strategies for Teachers. Virgnia, USA: arthur L. Costa, Bena Killick; 2009.

28. Trinchero R, Sala G. Chess training and mathematical problem-solving: the role of teaching heuristics in transfer of learning. Eurasia J Math Sci Technol Educ. 2016;12:655-68.

29. Waters AJ, Gobet F, Leyden G. Isuospatial abilities of chess players. J Psychol. 2002;93:557-65.

30. Santamaría P, Arribas D, Pereña J, Seisdedos N. EFAl: evaluación Factorial de las Aptitudes Intelectuales. Madrid: tea Ediciones: 2014.

31. Martin MO, Mullis IV. Relationships among Reading, Mathematics, and Science Achievement at the Fourth Grade--Implications for Early Learning. Boston E.U; timss and PIRLS International Study Cente; 2013.

32. Logothetis NK. What we can do and what we cannot do with fMRI. Nature. 2008;453:869.

33. Ogawa S, Lee TM, Kay AR, Tank DW. Brain magnetic resonance imaging with contrast dependent on blood oxygenation. Proc Natl Acad Sci. 1990;87:9868-72.

34. Campitelli G, Gobet F, Parker A. Structure and stimulus familiarity: a study of memory in chess-players with functional magnetic resonance imaging. Span J Psychol. 2005;8:238-45.

35. Bilalić M, Langner R, Erb M, Grodd W. Mechanisms and neural basis of object and pattern recognition: a study with chess experts. J Exp Psychol Gen. 2010:139:728-42.

36. Duan X, He S, Liao W, Liang D, Qiu L, Wei L, et al. Reduced caudate volume and enhanced striatal-DMN integration in chess experts. Neuroimage. 2012:60:1280-6.

37. Wan X, Nakatani H, Ueno K, Asamizuya T, Cheng K, Tanaka K, et al. The neural basis of intuitive best next-move generation in board game experts. Science. 2011;331:341-6.

38. Saariluoma P. Chess and content-oriented psychology of thinking. Psicológica. 2001;22:1-143

39. Powell JL, Grossi D, Corcoran R, Gobet F, García-Fiñana M. The neura correlates of theory of mind and their role during empathy and the game of chess: a functional magnetic resonance imaging study. Neuroscience. 2017;355:149-60.

40. Li K, Jiang J, Qiu L, Yang X, Huang X, Lui S, et al. A multimodal MR dataset of professional chess players. Scientific. 2015;2:1-9.

41. Chen X, Zhang D, Zhang X, Li Z, Meng X, He S, et al. A functional MRI study of high-level cognition. II. The game of GO. Brain Res Cogn Brain Res. 2003:16:32-7.

42. SEP. Modelo Educativo Para la Educación Basica; 2017. Available from: https://www.gob.mx/cms/uploads/attachment/file/198738/Modelo_Educativo_para_la_Educacio_n_Obligatoria.pdf. [Last accessed on 2017 Seb 07]

43. SEP. Prueba Enlace; 2016. Available from: http://www.enlace.sep.gob. $\mathrm{mx} /$ content/gr/docs/2013/historico/00_EB_2013.pdf. [Lst accessed on 2016 Seb 07]

44. OCDE. PISA Resultados Clave; 2016. Available from: https://www oecd org/pisa/pisa-2015-results-in-focus-ESP.pdf. [Last accessed 2016 Sep 10]. 